\title{
POST-OCCUPANCY EVALUATION (POE) OF JEDDAH RUSH HOUSING PROJECT
}

\author{
Hisham Mortada \\ Dept of Architecture College of Environmental Design King Abdul Aziz \\ University Jeddah, Saudi Arabia
}

(Recieved November 8, 2007 Accepted December 1, 2007)

\begin{abstract}
After its completion, the so-called "Rush Housing" project of Jeddah, Saudi Arabia that consists of high-rise residential buildings remained unoccupied for many years due to skepticism by the housing authority of some social, urban and environmental problems it might engender. Nonetheless, in the middle of the 1990s, the housing authority distributed these towers to eligible Saudi families. Since its occupancy, and as expected, the project has become a source of social and urban decay in the city.

This study evaluates the social problems that have been associated with the residency of Jeddah Rush Housing towers. It examines the inhabitants' satisfaction with the design and other aspects of the project. It also surveys the social and other problems that have been affecting the daily life of residents of this complex.
\end{abstract}

KEYWORDS: Public housing, Jeddah, slums, social disintegration, towers.

\section{INTRODUCTION}

For many people, a home is more than just a shelter. It is rather a subjective and personal place in connection with social, psychological and cultural dimensions of life. Most importantly, it is a space that affects the general satisfaction of human beings with their life. Its environment also influences the social and physical connections of the person with the surrounding complex world. Based on analyses of a number of studies, it has been recognized that the satisfaction of residents with their houses affects their psychological and physical health, which has a significant role in the improvement of the structure of society [1].

Home or its environment comes in various physical forms; one of them is public housing, which provides accommodation (home) for many families by economizing on house production, land costs and financial sources. It also provides open and shared areas for those who live in it and makes it possible to share these facilities [2]. The physical characteristics of housing and its environment guarantee the physical and psychological safety of people and social and physical welfare as well as their satisfaction and happiness. The satisfaction of house users with the housing environment is important because individuals or family groups may reside in any given residential unit for a long period of time. If this residential area is not designed suitably for its users, the users may be negatively affected [3]. The features of users as well as managerial, environmental and location aspects have a great impact on the 
satisfaction of residents and the way they react inside and outside their housing environment [4].

Sometimes when there is a tremendous increase of population that is associated with a limitation of housing, governments would forcefully react as expeditiously as possible to handle the situation before it aggravates. This was the case of Saudi Arabia in the 1970s, when the government constructed "RUSH" housing projects of high-rise buildings in various parts of the country, including Jeddah. This happened at the time when the other side of the world, the US in particular, was investigating such a type of housing due to physical and social problems it created. The result was the demolishing of the towers of these projects in cities such as PruittIgoe, Boston, Chicago, and Edinburgh (Fig. 1). In his book "Behind Ghetto Walls", the sociologist Lee Rainwater condemned this kind of housing as a "federally built and supported slum". His study outlined the failure of Pruitt-Igoe housing project saying that it was nothing than its vacancies; crime, safety concerns and physical deterioration were unsurpassed by any other public housing complex in the nation [5].



Pruitt-Igoe, 1972

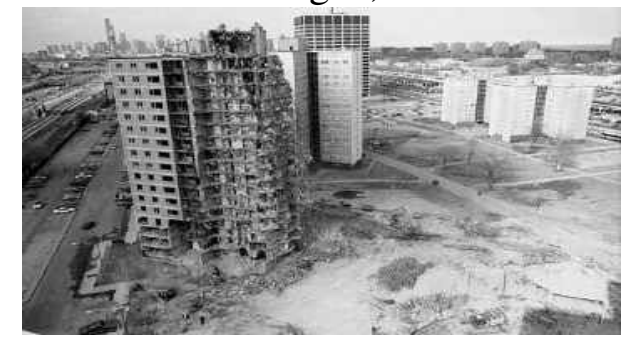

Chicago, 1999

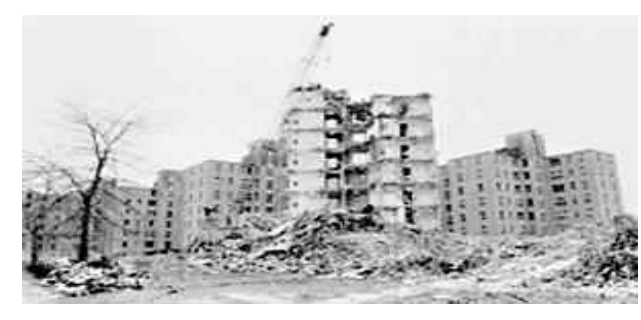

Boston, 1985

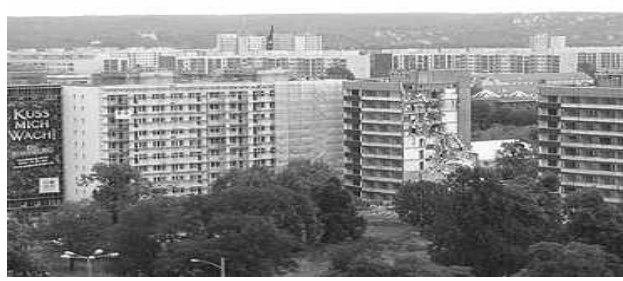

Edinburgh, 1991

Fig. 1. The demolition of high-rise public housing projects in the US and UK Source: [6 and 7]

As it is often necessary to asses the satisfaction of housing users with their housing environment and its compliance with their expectations, needs and goals, this study is to investigate the satisfaction of the residents of Jeddah Rush Housing Project with their environment. It aims to define and evaluate the social and physical issues of this project. As this research is the first evaluation conducted on post-occupancy of Jeddah Rush Housing Project, the findings would hopefully help to decide about the house performance in the environment in relation to its physical, social, institutional and psychological components. 
The study begins with a general discussion of the introduction of public housing to Saudi Arabia. Following this, an account of design and other relevant information of Jeddah rush housing project is given. This culminates a survey, the core of this study, conducted in 2005/6 and its results and conclusion.

\section{PUBLIC HOUSING IN SAUDI ARABIA}

The history of public housing in Saudi Arabia could be divided into four eras:

- $\quad$ King Abdul Aziz's Hejar Project

- ARAMCO Housing

- The Ministry of Housing

- The Real Estate Development Fund (REDF)

\subsection{King Abdul Aziz's Hejar Project}

The first attempt to setup public housing in Saudi Arabia was in 1910 by King Abdul Aziz, the unifier/founder of modern Saudi Arabia. The ultimate objective was to settle the Saudi beduins/nomads in communities or hamlets (Hejar pl. of Hejra, meaning a hamlet) in order to create a settled society that would contribute to the development of the county. In other words, the King, who was personally following up the execution of the project year after another, was keen in settling these nomads, teaching them agricultural skills and housing them in dwellings a group of which formed a hamlet or Hejra. He thought that such a project would transform these nomads into an urban society instead of leaving them helplessly strewn in the desert.

Accordingly, a site for each hamlet was selected on the base of availability of water resources such as wells or springs that were necessary for daily life and irrigation. Also most Hejra were located on plain lands previously used for pasturing. In order to create a sense of community and spatial/territorial belonging, the settlers were given building materials to construct their houses and communal structures such as mosques, as well as agricultural equipments by the government. In his lifetime, King Abdul Aziz was able to set up 173 settlements that housed groups from more than 15 tribes in Saudi Arabia [8].

\subsection{The ARAMCO Experience}

The Arabian American Oil Company (ARAMCO), who constructed housing compounds for its employees in the Eastern Province of Saudi Arabia in the late 1940s, initiated the idea of public housing in the Western sense for the first time in the country. These compounds which consisted of various types of housing buildings contained hospitals, schools and other amenities for the growing number of ARAMCO's experts (Fig. 2). This encouraged the Saudi government, especially after transferring its offices from Jeddah and Mecca to the capital of Riyadh, not only to setup a housing project for its relocated employees, but also to consider a long-term housing policy for the entire country in 1953. This policy was translated in 1970s in the establishment of the Ministry of Housing, which constructed housing projects in almost every major Saudi city. 


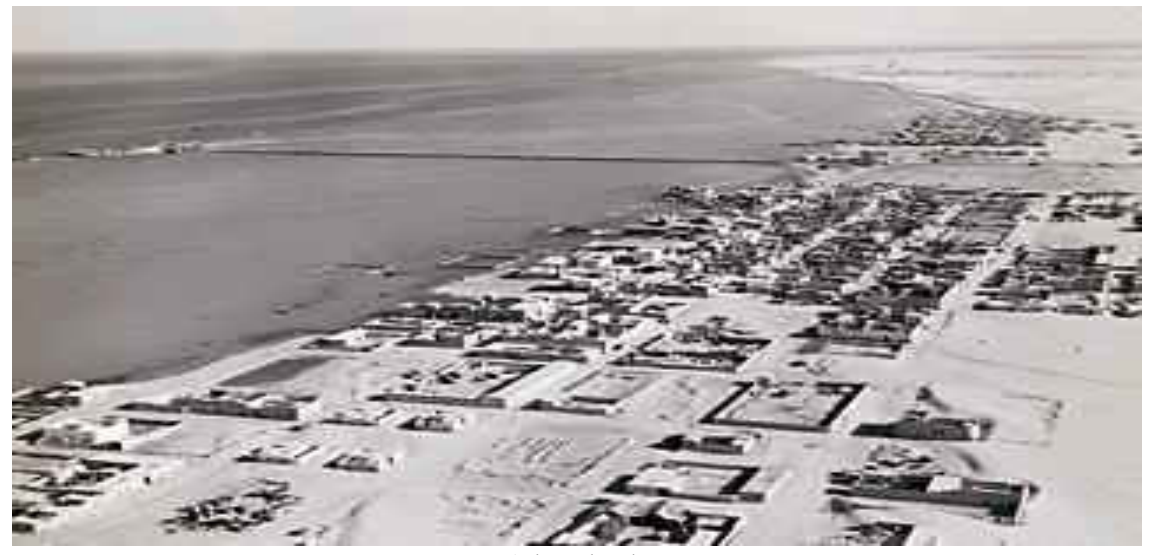

Al-Khobar

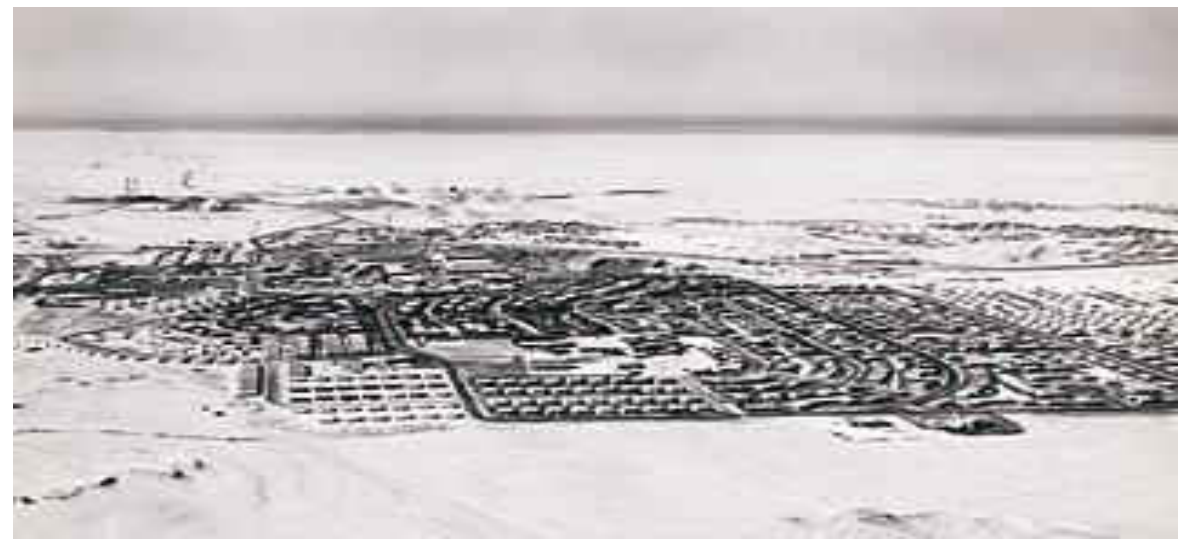

Dhahran

Fig. 2. ARAMCO Housing, Eastern Province, 1940s

Source: [9]

\subsection{The Ministry of Housing and Public Works}

As the first Five Year Development Plan (1970-75) of Saudi Arabia recommended, a general administration for housing was established in 1971 under the supervision of the Ministry of Finance and National Economy. Its purpose was provision of housing units to Saudi citizens [10].

In 1975 the General Administration of Housing was replaced by the Ministry of Housing and Public Works, which was set up as part of a package of six ministries newly found to expand and improve governmental services to citizens. The objectives of this Ministry were as following:

- Planning and improving public works and housing in Saudi Arabia.

- Constructing new housing projects as well as supervising their engineering works, drawings and research of these projects.

- Conducting housing surveys and statistics.

- Registering and qualifying contractors [11]. 
Within a short time, the Ministry was able to construct twelve housing projects in nine major Saudi cities. These projects, which were provided with all kinds of public facilities and infrastructure such as roads, parks, parking, schools, mosques, children playgrounds, as well as electricity, telephone, water and sewer networks, were of two types: regular public housing and rush housing.

\subsubsection{Public Housing Projects}

These projects consisted of low-rise apartment buildings and separate housing units (villas) of one floor that was extendable (Table 1). They were built in Mecca, Medina, Riyadh, Jeddah, Al-Khobar, Buraidah, Al-Hassa and Qatif (Fig. 3).

\subsubsection{Rush Housing Projects}

As highly suggested by the first three Five Year Development Plans, the Ministry of Housing constructed three rush housing projects in Riyadh, Jeddah, and Dammam. They were high-rise towers that totally dependent on the infrastructure of these cities (Fig. 4).

The total housing units of these rush projects are 4752 units. The average area of an apartment is 226-232 $\mathrm{m}^{2}$ and includes 3 bedrooms, a guest room, a dinning room, a living room, a kitchen, and 3 balconies. The Ministry claims that these units have been designed in accordance with local social customs and family needs with for example a separation between male guests' section and that of the family [10] (Table 2).

Although the construction of these projects was finished in 1980, they remained unoccupied for more than eleven years due to some skepticism of the social, urban, and environmental problems they would produce. Nonetheless, in 1991 these projects were opened to shelter Kuwaiti families who fled their country during the Kuwait liberation war [12]. After the end of the war, thus the retain of Kuwaitis to their country, the Ministry of Housing handed the units of these projects to the Real Estate Development Fund (REDF), another governmental agency, to distribute them to qualified Saudi citizens.

The Ministry of Housing was brought down to an end in 2001, when the government thought that the Ministry has achieved its aims. By that time the Ministry has constructed 24540 units (14686 apartments and 9854 villas). They were built on 3793 lots that were well serviced and prepared for construction.

\subsection{Real Estate Development Fund (REDF)}

A royal decree has established this agency in 1972 to provide Saudi citizens with opportunities to construct their houses or invest in real estate. In other words, this fund/agency aimed to encourage construction of houses by the private sector by offering citizens long-term loan free of interest [8].

The establishment of REDF was necessary in order to meet the urgent demand for housing. Its significant effect was the escalation of the construction boom in Saudi Arabia in the mid 1970s. 
Table 1. Public housing projects constructed by the Ministry of Housing and Public Works

\begin{tabular}{|l|l|l|l|l|l|l|l|l|}
\hline City & $\begin{array}{l}\text { Project } \\
\text { Area } \\
\mathrm{m}^{2}\end{array}$ & $\begin{array}{l}\text { No. of } \\
\text { Buildings }\end{array}$ & $\begin{array}{l}\text { No. } \\
\text { of } \\
\text { Apts. }\end{array}$ & $\begin{array}{l}\text { No. } \\
\text { of } \\
\text { Villas }\end{array}$ & $\begin{array}{l}\text { No. of } \\
\text { Developed } \\
\text { Lots }\end{array}$ & $\begin{array}{l}\text { No. of } \\
\text { Units } \\
\text { in the } \\
\text { Project }\end{array}$ & $\begin{array}{l}\text { Unit } \\
\text { Area } \\
\mathrm{m}^{2}\end{array}$ & $\begin{array}{l}\text { Density } \\
\text { (person/ } \\
\text { hectare) }\end{array}$ \\
\hline Mecca & 2500000 & - & - & 2592 & - & 2592 & 231 & 60,7 \\
\hline Medina & 2500000 & - & - & 2084 & - & 2084 & 244 & 48,8 \\
\hline $\begin{array}{l}\text { Riyadh } \\
\text { (Al- } \\
\text { Kharj) }\end{array}$ & 6500000 & 135 & 2408 & 2633 & - & 5041 & $\begin{array}{l}200- \\
236\end{array}$ & 45,4 \\
\hline $\begin{array}{l}\text { Riyadh } \\
\text { Al- } \\
\text { Jazerah) }\end{array}$ & 5300000 & - & - & 1258 & 2118 & 1258 & 235 & 37,3 \\
\hline Jeddah & 2736360 & 188 & 3420 & - & - & & & \\
\hline $\begin{array}{l}\text { Al- } \\
\text { Khobar }\end{array}$ & 1325000 & 219 & 4106 & - & - & 4106 & 241 & 181,3 \\
\hline Buriydha & 3680000 & - & - & 949 & 1675 & 949 & 236 & 41,7 \\
\hline Hassa & 1000000 & - & - & 400 & - & 400 & 236 & 23,4 \\
\hline Qatif & 320000 & - & - & 600 & - & 600 & 236 & 109,7 \\
\hline Total & 25861360 & 542 & 9934 & 10516 & 3793 & 20450 & - & - \\
\hline
\end{tabular}

Table 2. Rush housing projects constructed by Minister of Housing and Public Works

\begin{tabular}{|l|l|l|l|l|l|l|l|}
\hline City & $\begin{array}{l}\text { Project } \\
\text { Area } \\
\mathrm{m}^{2}\end{array}$ & $\begin{array}{l}\text { No. of } \\
\text { Buildings }\end{array}$ & $\begin{array}{l}\text { No. of } \\
\text { Residential } \\
\text { Floors }\end{array}$ & $\begin{array}{l}\text { No. of } \\
\text { Apartments } \\
\text { in each } \\
\text { Floor }\end{array}$ & $\begin{array}{l}\text { No. of } \\
\text { Apts } \\
\text { in the } \\
\text { Project }\end{array}$ & $\begin{array}{l}\text { Apartment } \\
\text { Area } \\
\mathrm{m}^{2}\end{array}$ & $\begin{array}{l}\text { Density } \\
\text { (person } \\
\text { /hectare) }\end{array}$ \\
\hline Riyadh & 190591 & 24 & 8 & 6 & 1162 & 226 & 353,6 \\
\hline Jeddah & 1000000 & 32 & $15-16$ & 4 & 1936 & 232 & 113,3 \\
\hline Dammam & 350000 & 32 & 13 & 4 & 1664 & 232 & 278,1 \\
\hline Total & 1540591 & 88 & - & - & 4752 & - & - \\
\hline
\end{tabular}

Source: [13 and 10]

The sever shortage in housing and tremendous increase in population due to large numbers of immigrants to major cities from inside and outside the country necessitated the construction of Rush Housing Projects and the setting up of the REDF. Regardless of these efforts and the achievements of the Ministry of Housing and the REDF in tackling this housing shortage, house ownership in Saudi Arabia is still extremely low. It is estimated that only $22-25 \%$ of Saudis own their houses. Yet, the Minster of Economy and Planning lately denied this information. He said that the 
census conducted early 2007 by the Agency of National Statistics revealed that $62 \%$ of Saudis owned their houses. He indeed stressed that housing has been a major issue emphasized in the last Five Year Development Plan. He added that the Saudi Government has recently assigned more than USD 3 billions for social housing in the country [14].



Mecca

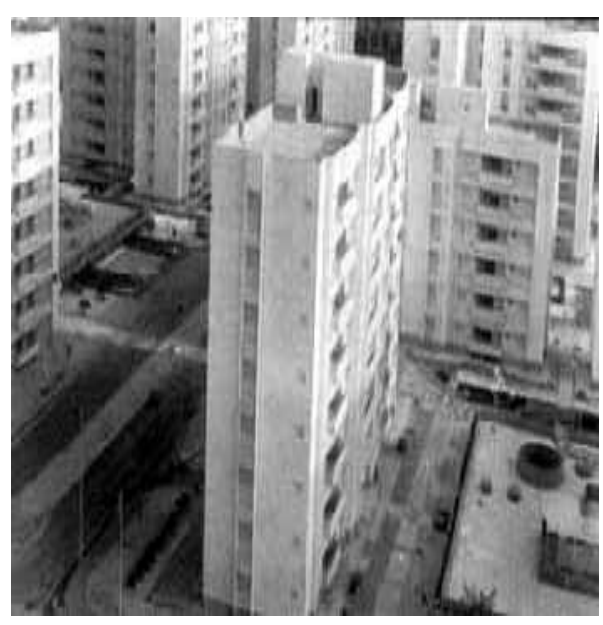

Al-Khobar

Fig. 3. Examples of public housing projects built by the Ministry of Housing Source: [8]

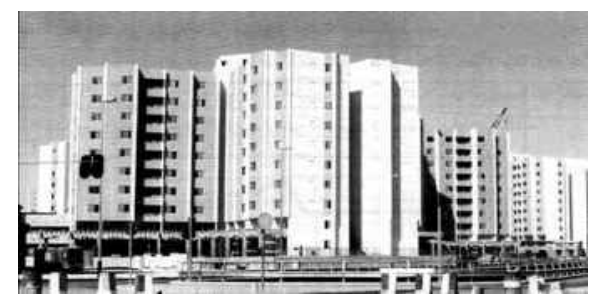

Riyadh

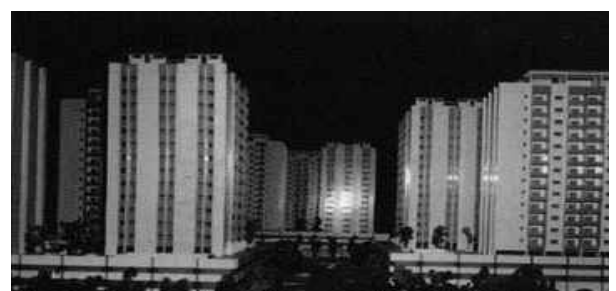

Dammam



Fig. 4. Rush Housing projects built by the Ministry of Housing Source: [10] 


\section{JEDDAH RUSH HOUSING PROJECT}

\subsection{Design Characteristics}

The project is located in al-Sharafiah District, on a major intersection of two main traffic spines (King Fahd Street and Kind Abdul Allah Road) of Jeddah. Executed in less than 3 years (1977-79), this project aimed to accommodate the maximum possible number of people in the shortest time in the most economic means within a proper environment. It is constructed on a lot of $150,521 \mathrm{~m}^{2}$ with a built up area of $535,13 \mathrm{~m}^{2}$, and designed to house 1,930 families in a self-sufficient neighborhood where walk-up and high-rise apartment buildings would be incorporated. The project consists of 1,936 apartment units distributed between 32 towers, each of which measures 40 x $48 \mathrm{~m}$ on plan. The towers, each includes 60 apartments, are grouped into eight $100 \times 100 \mathrm{~m}^{2}$ clusters constructed on a podium of three storeys assigned for commercial, office, storing, and parking uses. There are 182 shops and 60 offices. Above is constructed four residential towers of fifteen storeys each. In each floor 4 apartments are grouped around elevators, emergency exists and utility rooms. Areas for other facilities such as mosques, clinics, schools and municipal offices are distributed between the clusters.

Each apartment covers an area of $220 \mathrm{~m}^{2}$ and includes 3 bedrooms, a guest room, a living room, a kitchen, 3 bathrooms, and 2 balconies. Pre-fabrication was used in the construction of the entire project mainly to achieve rapidity and high quality construction [8 and 15] (Figs. 5-8).

\subsection{Managerial Characteristics}

After the distribution of the units of Jeddah Rush Housing Project to qualified citizens, the Ministry of Finance and National Economy in 1997 has set up a committee to supervise the project. The ultimate responsibility of this committee was managing and maintaining the public utilities of the complex. Later, in 1999 the objective and responsibilities of this committee were clarified and detailed. The objective was meeting logical demands and within available resources, of basic issues such as precautionary maintenance of the project. That was the maintenance of the shared spaces and utilities such as electricity, water, and sewer pipes and pumps.

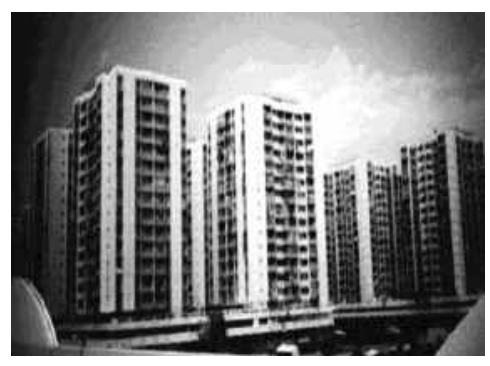

Fig. 5. External view of Jeddah Rush Housing Project

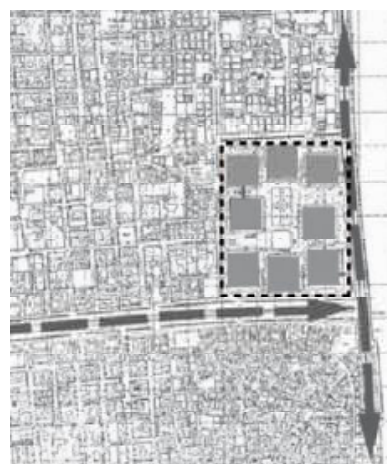

Fig. 6. Location of the project in the heart of Jeddah

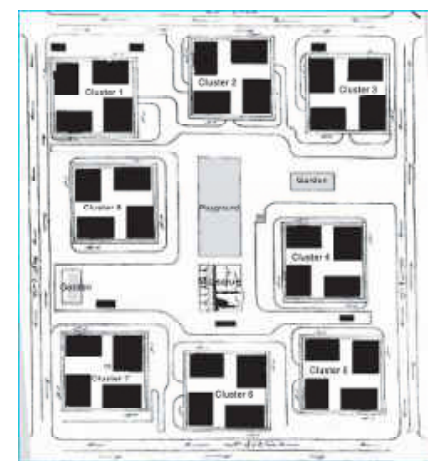

Fig. 7. Site Plan

Source: Adopted and developed from [16] 




Fig. 8. Typical plan of a residential floor

Source: Adopted and developed from [16]

\subsection{Managerial Characteristics}

After the distribution of the units of Jeddah Rush Housing Project to qualified citizens, the Ministry of Finance and National Economy in 1997 has set up a committee to supervise the project. The ultimate responsibility of this committee was managing and maintaining the public utilities of the complex. Later, in 1999 the objective and responsibilities of this committee were clarified and detailed. The objective was meeting logical demands and within available resources, of basic issues such as precautionary maintenance of the project. That was the maintenance of the shared spaces and utilities such as electricity, water, and sewer pipes and pumps.

As far as responsibilities, they were as following:

- Making decisions on the maintenance of shared areas and services starting from the building gate to the unit entrance.

- Collecting annual maintenance fees (USD 367) from householders.

- Supervising the change of the unit ownership or lease.

- Conducting any activity that would improve the project physical performance and increase its usage efficiency.

- Meeting annually with owners or their representatives to exchange views on the work of the committee and receive their comments and suggestions [15].

The total number of the committee members is six. Three are from the REDF and the rest are from the residents. The committee's financial resources are as following:

- Annual maintenance fee (USD 367) paid by each unit

- Loans

- Rentals of common areas (i. e. gardens) of the project. In 2000, the Committee rented the main garden to a private company to operate it as an amusement park for USD 53,000 a year. It also made USD 13,333 from leasing a spot on the roof of a tower to a telecommunication company. 
In addition to the Supervision Committee, an elected representative of each tower has a sort of an administrative role in Jeddah Rush Housing Project. The duties of this person are as follows:

- Representing the residents of his building in the Committee and conveying their demands and needs.

- Maintaining a good order inside the building.

- Collecting guarding and cleaning fees.

- Attempting to create strong social relationships between residents.

- Notifying the Committee of any serious damage or incident that might occur in his building.

- Assisting in educating the residents on how to take good care of their unit and the building.

- Working on the safety of the residents of his building.

- Providing the Committee with any information concerning the residents' attitudes toward their units and building.

- Preventing any wrongdoing in his building and assisting in removing it [15].

As part of its responsibilities, the Committee periodically publishes a newsletter reminding residents of the following duties:

- Cooperating with the building representative and other residents for the welfare of the community.

- Notifying the Committee of any offense related to the maintenance of the building or misuse of any equipment or area (e. g., elevators, garages, gardens, sidewalks, etc.) of the complex.

- Avoiding any modification to the structure of the unit or the color of the external wall, or use any space outside the unit for individual benefit.

- Conducting regular basic maintenance inside the unit.

- Preventing children from playing with electrical switches, elevators or any element or equipment outside the unit [15].

\section{THE SURVEY}

In December 2005, the author with the assistance of 16 students conducted a survey of Jeddah Rush Housing Project. The aim of the survey, which carried out in 14 weeks, was to determine the residents' level of satisfaction concerning specific design and planning aspects of the project. Also, the author was keen in finding out the actual social and other issues of the post-occupancy of the complex.

\subsection{The Technique}

In order to expose the level of residents' satisfaction and explore the social matters of Jeddah Rush Housing Project, the survey consisted of two techniques: door-to-door questionnaire distribution and interviews.

\subsubsection{Questionnaire}

Prior to the design of the questionnaire, the author made several visits to the site in order to obtain more insight of the planning, design and social features of the project. 
In addition to information of various issues of this project the author collected at the beginning of the study, these visits greatly contributed to the design of the questionnaire.

The distribution of the questionnaire, which covered the entire project in terms of space, was carried out during the evening time (5-8 pm), when generally most male householders were in their houses. The time (20-30 minutes) a survey representative spent with a householder during the distribution and receiving a questionnaire allowed the resident to freely answer and express his views on the issues of the questionnaire.

Before handing a questionnaire, a survey representative identified himself to the selected householder, and explained the purpose and nature of the study. Once the householder agreed to participate, he was given the questionnaire.

Ten questionnaires were distributed in each tower. This means that the total number of the questioners distributed in the entire project (32 towers) were 320. An average of eight questionnaires were completely filled out in each tower. As a result, the study surveyed 256 units of the complex, representing $13.2 \%$ of the total number of units/families of the project.

\subsubsection{Questionnaire Design}

After multiple visits to the site, the author held expectations based on observations concerning pre-identified design issues and current use of the project. In addition to these probabilities, the questionnaire was also based on what local media has been publishing on social issues of the complex. Reviewing literature on similar projects built then demolished in the US and Europe due to their social complications, also assisted in the formulation of the questionnaire.

The questionnaire contained seven sections that were set in a manner presenting the questions that were the easiest to identify with first and then lead to questions that my have been more difficult to identify with last (Fig. 9). The questions within each section were arranged to create a logical sequence from the one question to the next. Some of them were designed in a rating scale while other contained options, with one option being either neutral or other. The only questions that did not contain any options were those that required a precise option or a yes or no answer. In order to give more freedom to the respondent to elaborate on his reply, an empty space followed some questions and entitled comments. In such a space, the participant had been given the opportunity to give more relevant information or state his stand on the issue of the question.

The sections that the questionnaire included are as following:

1. General Information: This section asked questions of education and ethnic background of residents. Also, the type of tenancy was questioned. These questions were vital in order to relate issues of other questions to the findings of this section.

2. Design Characteristics: In this section the resident was asked about his satisfaction or dissatisfaction with design aspects of his apartment and the project. These aspects concerned matters such as the suitability of apartment area to family size, local customs, privacy and current use of communal spaces or elements.

3. Social Issues: In order to find out the definite social atmosphere of this project, this section contained questions regarding the relationship with neighbors and 
other residents of the complex as well as social or moral problems that might exist in the project.

4. Maintenance Issues: From the site visits he had prior to the preparation of the questionnaire, the author felt that there was a significant maintenance problem in the complex. Therefore, this section intended to find out the seriousness level of this matter.

5. Security and Safety: Similar to the previous section, the purpose of this section was to examine the situation of security and safety in both the individual building and the entire project.

6. Resultant Views: This section asked residents of the most issues that were affecting their occupancy and if they were willing to continue living in this project regardless of the presence of these problems.

7. Final Comments: In this optional section, the residents were given the chance to state their final opinion on the project, its problems and any recommendations they might have.

\subsubsection{Interviews}

In addition to door-to-door questionnaire distribution, the survey included interviews of focus groups. During the questionnaire distribution, the survey representative asked the respondent if he was willing to be interviewed for more discussion. If the householder agreed, an appointment was ranged for a later time. The interviews were informal and took a place in the units of those who accepted to be met. The average time each interview took was 30-45 minuets and the number of the interviewed was 64 residents, an average of 2 units in each tower.

The reason for the interviews was that the author thought that residents should not be limited to the questions of the questionnaire. Participants were given more opportunity to freely speak out of issues that they were a source of concern.

\subsection{The Results}

Below lists and discusses the findings of the survey of the project.

\subsubsection{General Information}

\subsubsection{Education}

The survey has found that the householders of most units of the project were educated. Indeed, about half of them had a university education (Fig. 10). This means that those residents had enough knowledge of the meaning of responsibility toward their community and proper behavior.

\subsubsection{Ethnic Background}

Although the project was built for Saudi families, the survey has found that $74 \%$ of inhabitants were Saudi while $26 \%$ were non-Saudi (Fig. 11). This diversity in nationalities, thus in cultural backgrounds and daily lifestyles, should have an impact on the social integration among residents. 
Surveyor's Name:

Building No.:

Unit No::

Date:

Dear Resident:

\section{POST OCCUPANCY EVALUATION SURVEY}

I conduct this academic survey to determine your level of satisfaction with the design and planning of and your residency experience in Jeddah Rush Housing Project. I hope you answer all the questions below. I appreciate taking the time to fill out this survey. (Please attach additional comments if necessary).

Sincerely yours,

The Researcher, Dept. of Architecture, King Abdul Aziz University, Jeddah

\section{GENERAL INFORMATION}

1. Level of Education

[] University [] High School U] Middle []Elementary

\section{Citizenship}

U Saudi U Non-Saudi

3. Type of Tenancy

[1] Owner [] Renter

EVALUATION OF UNIT DESIGNE

1. Are you satisfied with the adequacy of the unit area to the size of the your family?

[] Satisfied [] Dissatisfied

Comments:

2. Are you satisfied with the suitability of the apartment design to your local customs?

[] Satisfied [] Dissatisfied

Comments:

3. Are your satisfied with the level of privacy available inside your apartment?

[] Satisfied [] Dissatisfied

Comments:

4. Have made any modification to the layout of your unit?

[] Yes [] No

Comments:

5. Are your satisfied with the current use of communal spaces and elements?

[] Satisfied

[] Dissatisfied

Comments:

6. Are your satisfied with the number of car parking spaces provided in the project?

[1 Satisfied

[] Dissatisfied

Comments:

7. Are your satisfied with the design of the children's playgrounds of the project?

[] Satisfied [] Dissatisfied

Comments:

EVALUATION OF SOCIAL ISSUES

1. How do you evaluate your relationship with your neighbors in the same building?
[] Strong
[] Limited
[] Doesn't exist

Comments:

2. How do you evaluate your relationship with residents of other buildings?

[] Strong [] Limited [] Doesn't exist

Comments:

First page of the questionnaire 
3. How do you evaluate cooperation between residents?

[] Strong [] Limited [] Doesn't exist

Comments: -

4. What are the major social problems in your building or the project?

[] Reckless behavior [] Sexual harassment [] Insecurity

Comments:

EVALUATION OF MAINTENANCE ISSUES

1. Are you satisfied with the maintenance of your unit?

[] Satisfied [] Dissatisfied

Comments:

2. Are you satisfied with the maintenance of the building or project?

[] Satisfied [] Dissatisfied

Comments:

3. Are you satisfied with the cleanness level of the project?

[] Satisfied [] Dissatisfied

Comments:

4. What are the reasons of damages in the building or the project?

[] Residents' irresponsibility [] Residents' ignorance [] Absence of penalty

Comments:

EVALUATION OF SECURITY AND SAFETY

1. Are you satisfied with the security of the car parking?

[] Satisfied [] Dissatisfied

Comments:

2. Are you satisfied with the security of the project?

[] Satisfied [] Dissatisfied

Comments:

3. What are the crimes that you have witnessed in the project?
[] Alcohol consumption
[] Sexual harassment
[] Theft
[] Suicide

Comments:

\section{RESULTANT POINTS OF VIEW}

1. What are the most issues affecting your life in the project?
[] Maintenance
[] Security in the project
[] Security in the parking garages

Comments:

2. Do you have any desire to leave the project?

[] Yes [] No

Comments:

FINAL COMMENTS

Second page

Fig. 9. The questionnaire distributed in the complex 


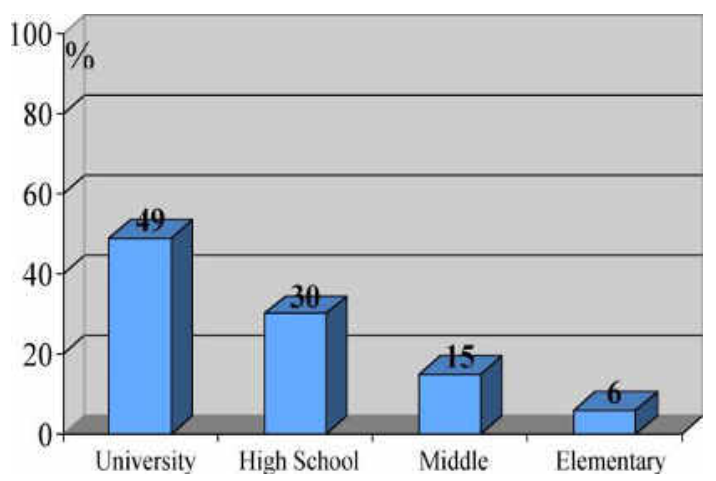

Fig. 10. Level of education among residents



Fig. 11. Ethnic distribution of residents

\subsubsection{Type of tenancy}

The project was constructed to shelter Saudi families who did not own a house due to their limited income. However, the survey found that some Saudi owners (34\%) have rented their apartments to other families (Fig. 12). This has in turn affected the project in terms of maintenance and social relationships. As the renters usually stayed in the complex for 2-3 years, they were not keen in participating in the maintenance or cleanness of the property, thus creating conflicts with neighbors.

\subsubsection{Design Characteristics}

\subsubsection{Adequacy of the unit area to family size}

According to the survey, there was a high rate of $68 \%$ of residents thought that the area of their apartment was suitable to the size of their family (Fig. 13). Nonetheless, $32 \%$ believed that the size was not enough to accommodate them specially when they received guests or visitors and/or the number of their children increased. This explains the conversion of some balconies into small rooms and sometime storing extra furniture in them, lobbies and building entrance.

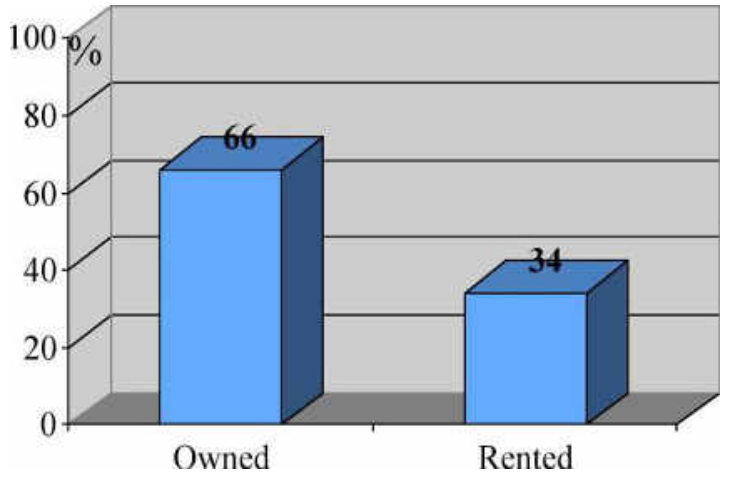

Fig. 12. Type of tenancy

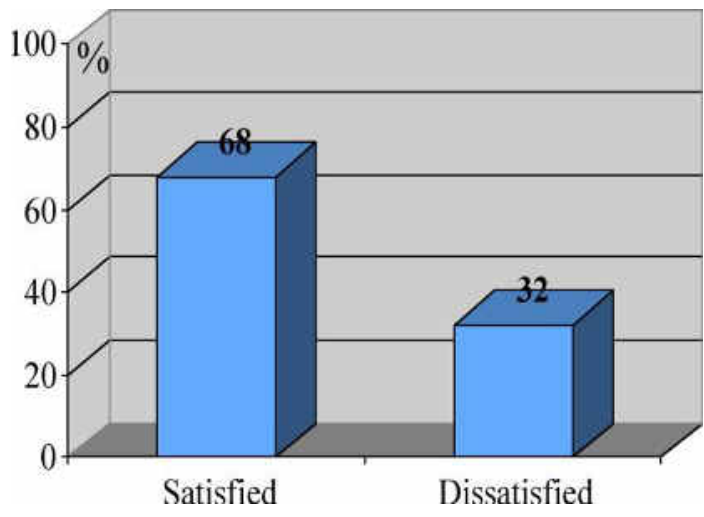

Fig. 13. Satisfaction with the area of the apartment in response to family size 


\subsubsection{Suitability of the unit design for local customs}

Unexpectedly, $78 \%$ of respondents said that the architectural design of their housing units suited their traditional Arabian customs (Fig. 14). They felt that the spatial arrangement of the unit was made with local norms in mind.

\subsubsection{Privacy}

$70 \%$ of those answered the questioners thought privacy inside their apartment was achieved by the design. Yet, $30 \%$ claimed that the closeness of the residential towers encouraged visual intrusion into their apartments from neighboring buildings (Fig. 15).

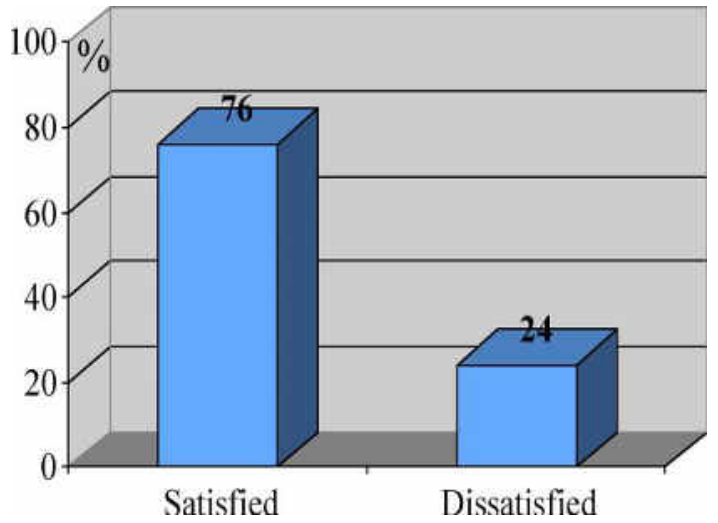

Fig. 14. Satisfaction with the suitability of the apartment design to local customs

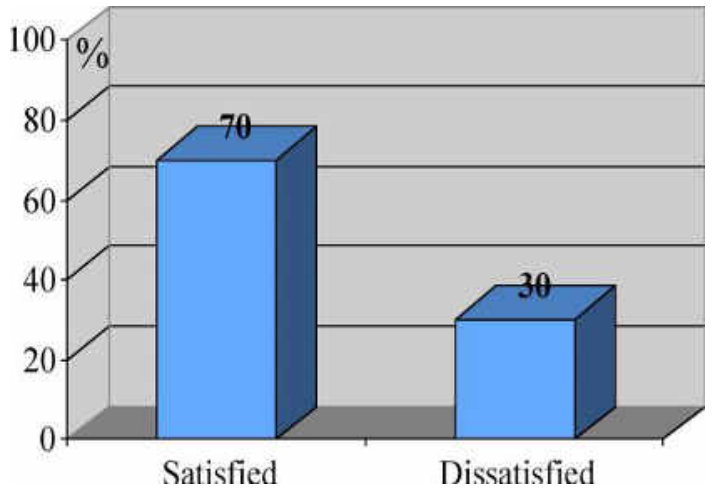

Fig. 15. Satisfaction with privacy inside the apartment

\subsubsection{Modification of the unit layout}

Regardless of the positive answers of above, the survey has found that $55 \%$ of residents have modified the unit layout in order to suite their needs (Fig. 16). This in fact violates the Supervision Committee's rule that prevents any modification to the layout of the unit.

\subsubsection{Current use of communal spaces and elements}

A high percentage of $63 \%$ of respondents were dissatisfied with the current use of common areas (lobbies, corridors, staircases, emergency exists, pedestrian sidewalks, etc.) and elements (i. e. elevators, lighting switches, etc.) (Fig. 17).

\subsubsection{Area of car parking}

It is interesting to notice that the majority ( $83 \%$ ) of residents believed that the number or area of the parking spaces provided in the project was sufficient (Fig. 18).

\subsubsection{Children's playgrounds}

$52 \%$ of residents revealed their satisfaction with the design of the children's playgrounds provided in the project. However, 38\% thought otherwise (Fig. 19). 


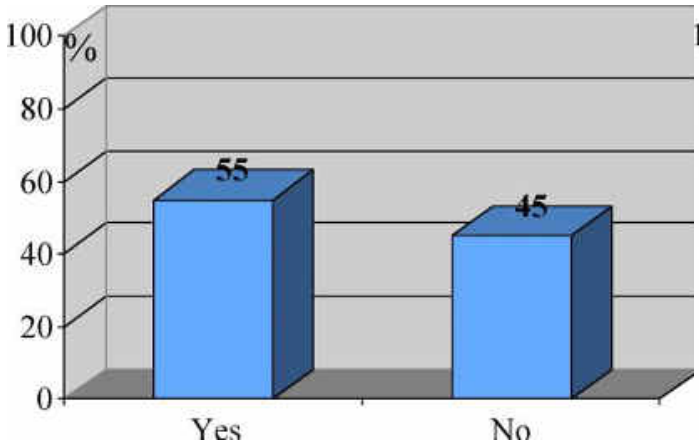

Fig. 16. Modification made to the unit layout

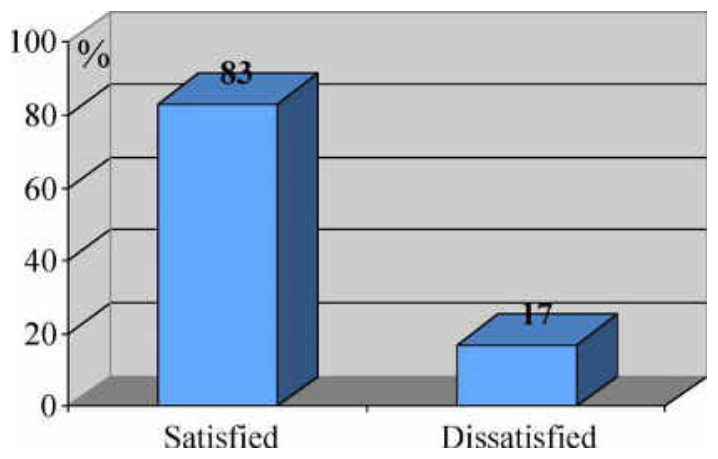

Fig. 18. Satisfaction with the area of car parking

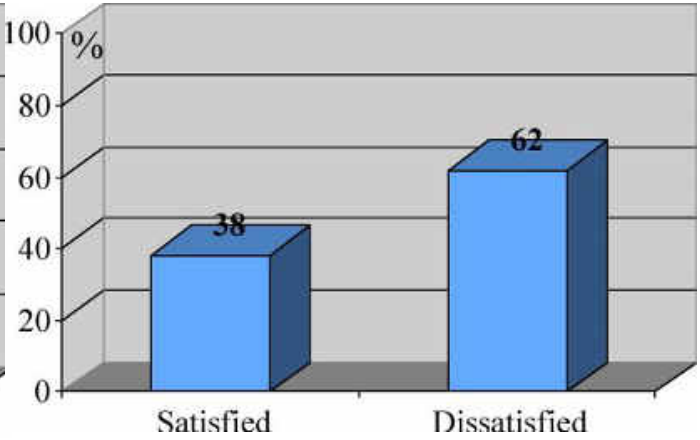

Fig. 17. Satisfaction with current use of communal spaces and elements



Fig. 19. Satisfaction with children's playgrounds

\subsubsection{Social Issues}

\subsubsection{Relationship with neighbors in the same building}

The survey has found that $74 \%$ of residents had negative impression on their relationship with neighbors in the same tower. While $38 \%$ of the respondents said that their relationship with their neighbors was limited, $36 \%$ did not have any neighborly relation at all (Fig. 20). However, 36\% believed that they had a strong contact with neighbors.

\subsubsection{Relationship with other residents of the project}

More than half $(53 \%)$ of residents did not have any social connection with residents of the other towers of the complex. Only $35 \%$ had a limited relationship while $12 \%$ had a strong contact (Fig. 21). 




Fig. 20. Social relationship with neighbors in the same buildings

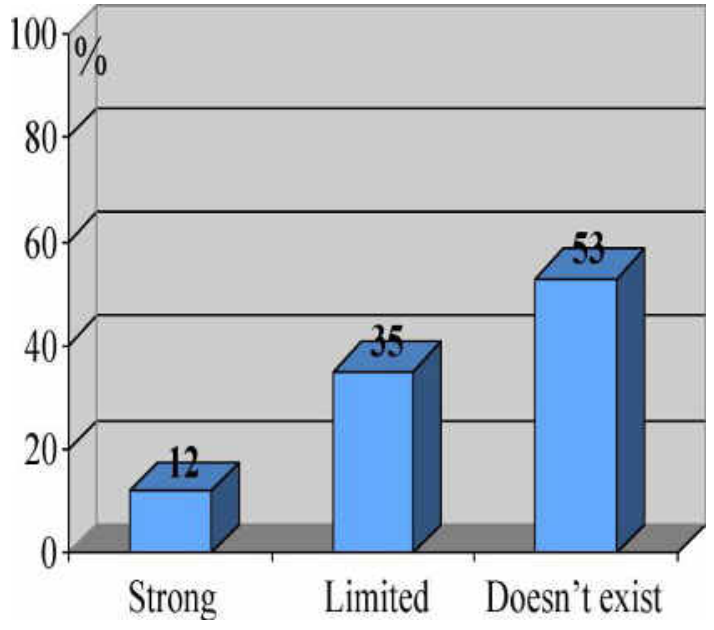

Fig. 21. Social relationship with other residents of the project

\subsubsection{Cooperation between Residents}

A high percentage of $44 \%$ of respondents claimed that there was no cooperation among residents of the same building. $34 \%$ said that there was cooperation but limited. It seems that the diversity of the ethnic and education background and type of tenancy as well as maintenance problems (discussed later) had some impact on this outcome. However, 22\% believed that there was a strong cooperation between residents (Fig. 22).

\subsubsection{Major social problems}

The predefined options of the answer of the question of this issue were: reckless behavior, sexual harassment and insecurity. The reason for specifying these options was related to similar projects that had the same problems as well was information the author found in local media resources on this project.

The survey has found that the vast majority $(80 \%)$ of residents were not happy with the security level in their building. In addition, 13\% thought that reckless behavior was a major problem. Sexual harassment existed in the project according to $7 \%$ of the residents (Fig. 23).

\subsubsection{Maintenance Issues}

\subsubsection{Unit maintenance}

Although the occupancy regulations of Jeddah Rush Housing Project made it clear that the maintenance of the inside of the unit was the responsibility of tenants, $71 \%$ of respondents were dissatisfied with this type of maintenance (Fig. 24). However, 29\% were satisfied. 


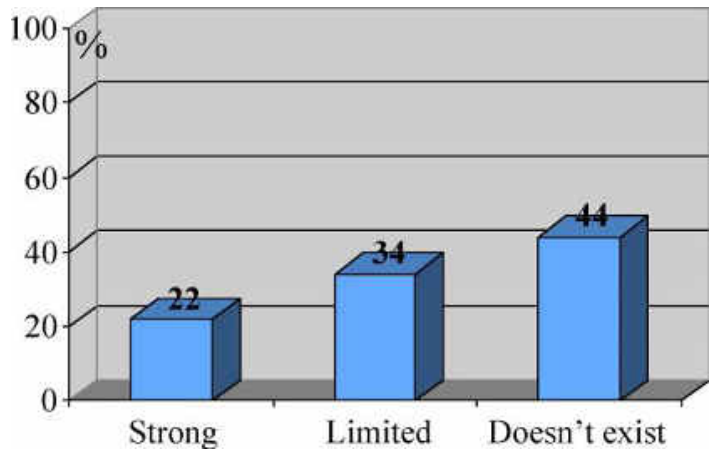

Fig. 22. Cooperation between residents of the same building

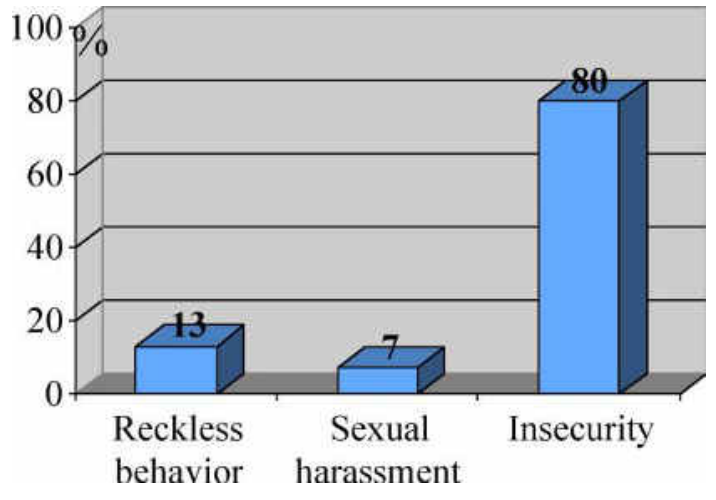

Fig. 23. Major social problems

\subsubsection{Building maintenance}

As previously discussed, the maintenance of the towers of Jeddah Rush Housing Project was the duty of the Supervision Committee. This maintenance included repairing any damages that might have occurred outside the unit. Only $41 \%$ of residents were satisfied with this maintenance while 59\% were dissatisfied (Fig. 25).

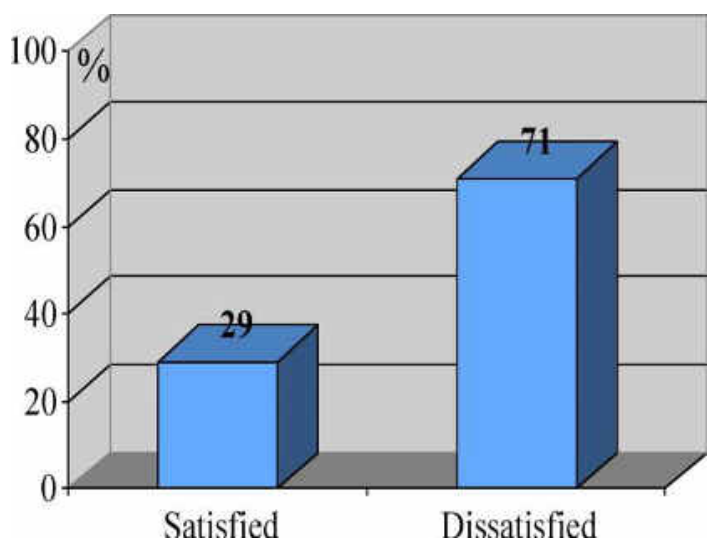

Fig. 24. Satisfaction with unit maintenance

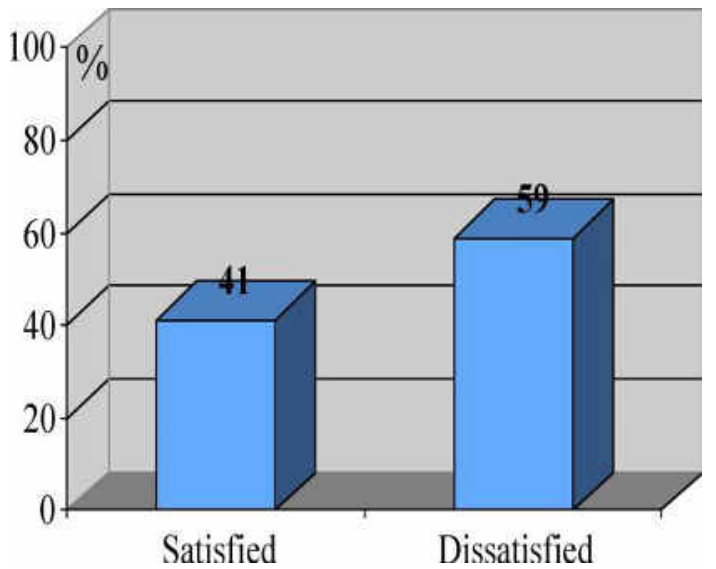

Fig. 25. Satisfaction with building maintenance

\subsubsection{Cleanness in the complex}

There was a negative reaction toward the level of cleanness of the project. A high rate of $83 \%$ of residents thought that public spaces such as parking garages, staircases, walkways and lobbies were unclean (Fig. 26). 17\%, however, thought differently.

\subsubsection{Reasons of damages in the building/project}

The predefined options of the answer of this question were: residents' irresponsibility, residents' ignorance and absence of penalty. While $40 \%$ of the respondents thought 
that absence of penalty was the main reason for damages in the building or complex, $39 \%$ believed that residents' irresponsible behavior was the reason. $21 \%$ said residents' ignorance (Fig. 27).

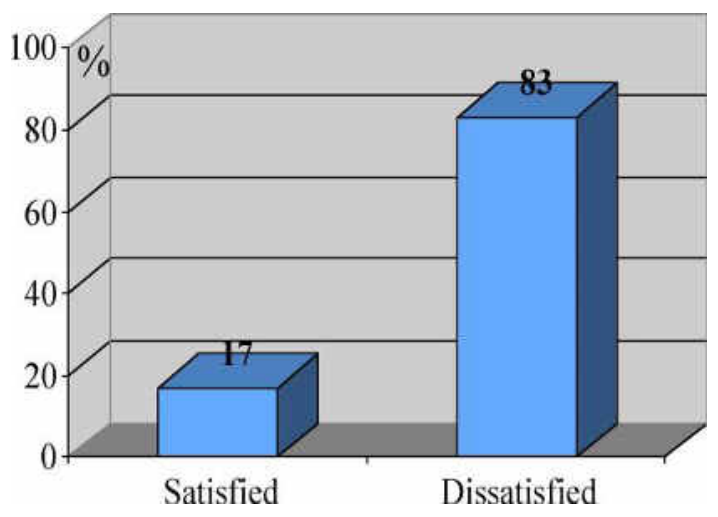

Fig. 26. Satisfaction with cleanness in the complex



Fig. 27. Reasons for damages in the building/project

\subsubsection{Security and Safety}

\subsubsection{Security of car parking}

The survey has found that $76 \%$ of inhabitants were dissatisfied with the level of security in the parking garages (Fig. 28). Nonetheless, $24 \%$ were satisfied.

\subsubsection{Security of the project}

A high rate of $75 \%$ of respondents was unhappy with the security of the project. As discussed in the following section of this study, there were several reasons for this dissatisfaction. Yet, 25\% were satisfied (Fig. 29).

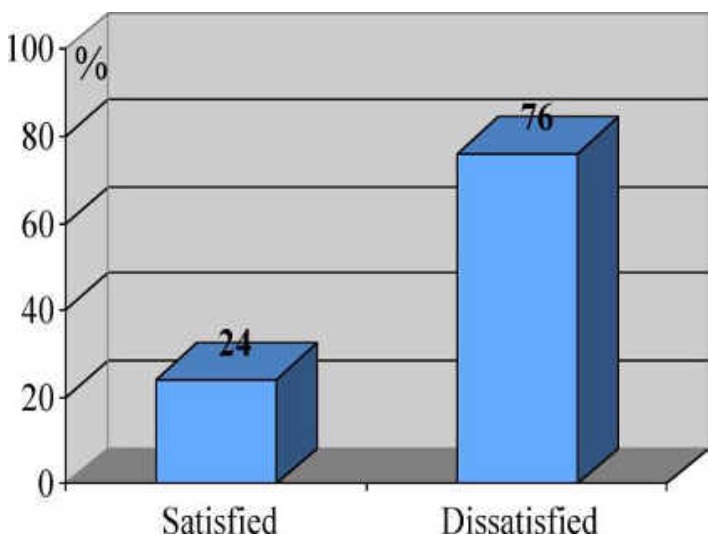

Fig. 28. Residents' satisfaction with security of parking



Fig. 29. Residents' satisfaction with security in the project 


\subsubsection{Crimes witnessed by residents in the complex}

According to the survey, theft was the most crime occurred in and witnessed by residents (48\%) of the complex (Fig. 30). 30\% of respondents said that they have witnessed sexual harassment, $16 \%$ alcohol and $6 \%$ suicide incidents.

\subsubsection{Resultant Views}

\subsubsection{Most issues affecting the life of residents}

$38 \%$ of residents thought that maintenance was the most issue affecting their life in the complex. While $32 \%$ believed that security in the complex was the issue, $30 \%$ said that they have been affected by the security of the parking garages (Fig. 31).



Fig. 30. Crimes witnessed by residents in the complex

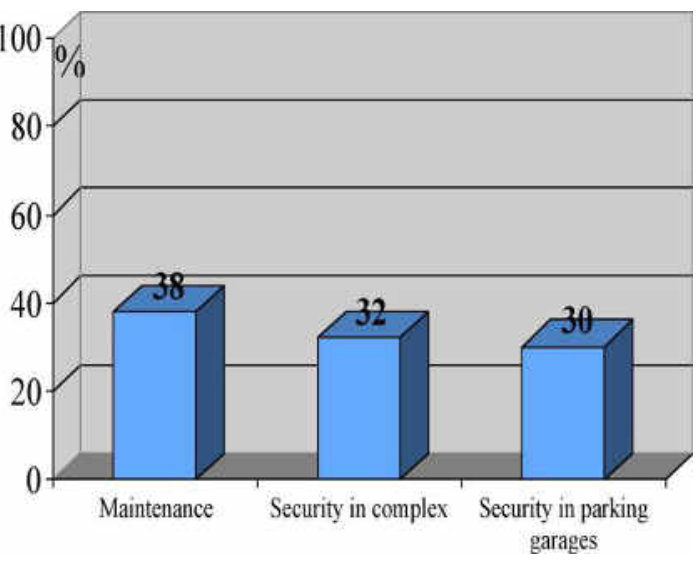

Fig. 31. Most issues affecting the life of residence in the complex

\subsubsection{Desire to leave the project}

The survey has found that due to the various social and maintenance problems discussed in this research, $68 \%$ of the respondents expressed their wish to leave the project. However, $32 \%$ thought they would remain (Fig. 32).

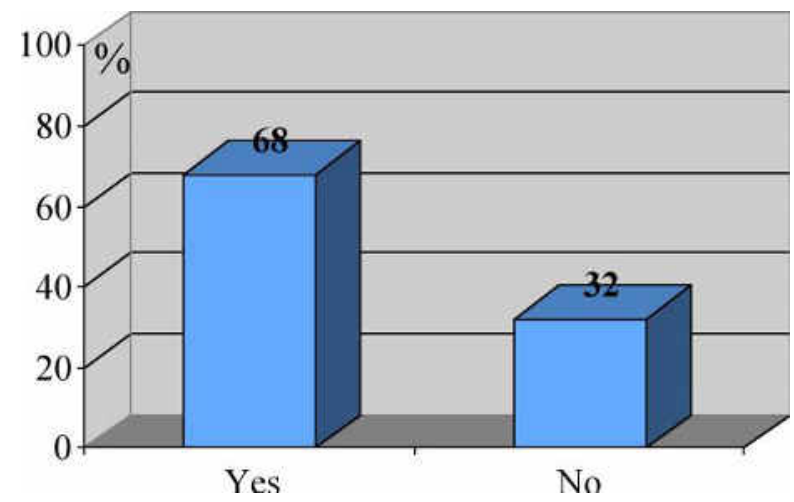

Fig. 32. Desire to leave the project 


\subsubsection{Comments by Residents}

As previously explained, each question in the questionnaire included a space where the respondent expressed his view on the issue of the relevant question. Below discusses these views as well as comments made by those who have been interviewed. Some issues are not discussed as they have not been commented on by residents.

\subsubsection{General Information}

4.2.7.1.1. Ethnic backgrounds: Many Saudi residents were not happy with the presence of non-Saudis in their building. They thought that such a variety has created some conflicts between them and neighbors.

This point of view was supported by one of the interviewed residents, who was a real estate expert and a member of the Real Estate Committee of Jeddah Chamber of Commerce. This person said that the units of the project were haphazardly distributed to different groups of different educational and ethnic/tribal backgrounds. Accordingly, there was no social homogeneity between residents. He also claimed that it would have been more appropriate if the units were offered to citizens of tribal backgrounds. He surprisingly added that the project should have been distributed on tribal bases. In other words, residents of the same tribe should have inhabited a particular tower or a group of towers. Alternatively, the project could have been divided into two separate parts: one for tribal residents and the other for urban.

4.2.7.2. Type of tenancy: Renting units of the Rush Housing Project of Jeddah is against the objective of this project. However, as this renting trend has been growing, the Supervision Committee has been forced to permit renting and start advertising units for lease in its newsletter [17].

\subsubsection{Design Characteristics}

4.2.7.2.1. Unit area: Although most residents were satisfied with the size of their apartment and thought it was adequate to the size of their family, closing balconies to create additional spaces has been growing in the project (Figs. 33). As a result, the external appearance of the project has been visually deteriorated. Satellite dishes hanged on the balconies or windows that have been built up for more privacy have aggravated this visual pollution (Fig. 34).

The unavailability of enough space for storing inside the unit has pushed some residents to place their unwanted items in the corridors adjacent to their unit or the building entrance lobby. This indeed has become a major obstacle for firemen in Dammam, where a similar project has been built. Some of these items blocked the emergency exits of the towers [18]. 




Converting balconies into interior spaces



Using public garage as a storage

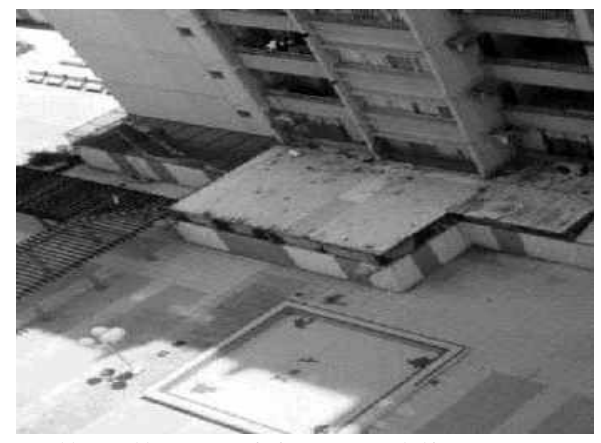

Illegally acquiring a public spaces



Storing extra furniture in communal spaces

Fig. 33. Means followed by residents to overcome shortage of space of their apartments

4.2.7.2.2. Privacy: Many residents complained about their unit being visually intruded by nearby towers. Hence, most of them blocked their windows with permanent panels (Figs. 35 and 36).



Fig. 34. Satellite dishes hanged on facade

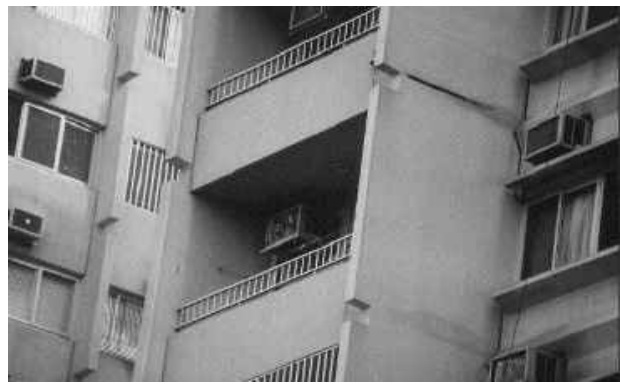

Fig. 35. Possible visual intrusion from neighboring units 


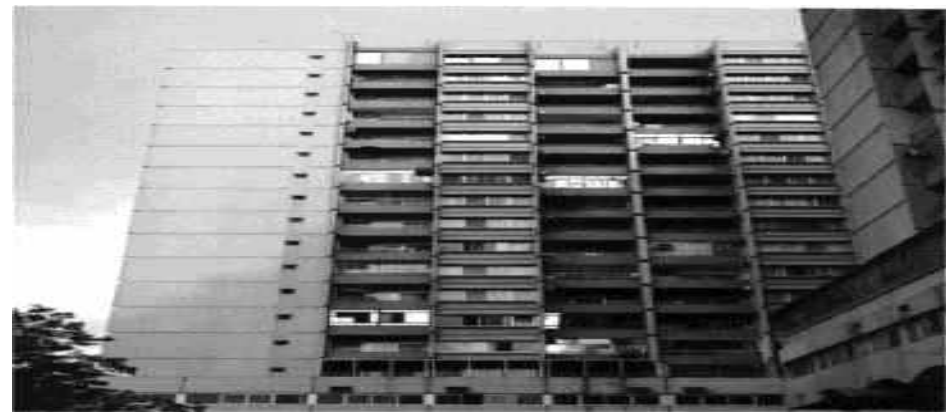

Fig. 36. Building up windows and balconies to maintain the indoor privacy

4.2.7.2.3. Current use of communal spaces and elements: According to some residents, emergency exits and stairways have been obstructed by garbage or extra furniture of other residents (Fig. 37). Also, several residents complained about the corridors or lobbies of the building being dark and not naturally lit. To them, pedestrian circulation was inadequate as it was mixed with vehicles. Improper parking blocked the walkways. Various residents chained some walkways turning them into private parking spaces.

A few residents wished if their outdoor spaces were greener while other said that elevators, light switches and fire extinguishers were damaged. A resident added that the reason behind such misuse and damage was that most residents were not accustoming to such lifestyle of sharing before moving to the project.

4.2.7.2.4. Parking spaces: Improper or misuse of the parking spaces was the ultimate reason for those residents who were not satisfied with the parking area of their building. Some said that their apartments were not assigned specific parking spots. They added that anyone from outside the complex could park in any spot for a long period without being questioned. In fact, some residents mentioned the presence of broken cars that have been parked in the garage for years (Fig. 38). They also complained that there were not visitors' parking spaces. Not only this, but also they pointed out a security issue in the garages. As there were no guards or security personals, car theft and vandalism have become popular in this area of the project (Fig. $39)$.

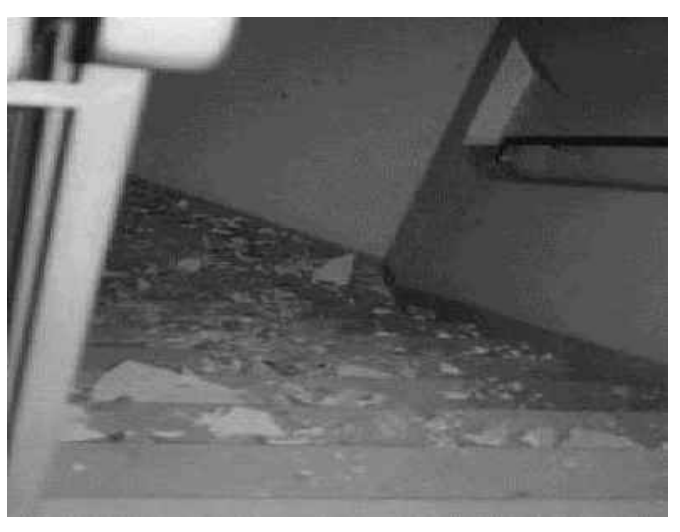

Fig. 37. Emergency staircase blocked with garbage

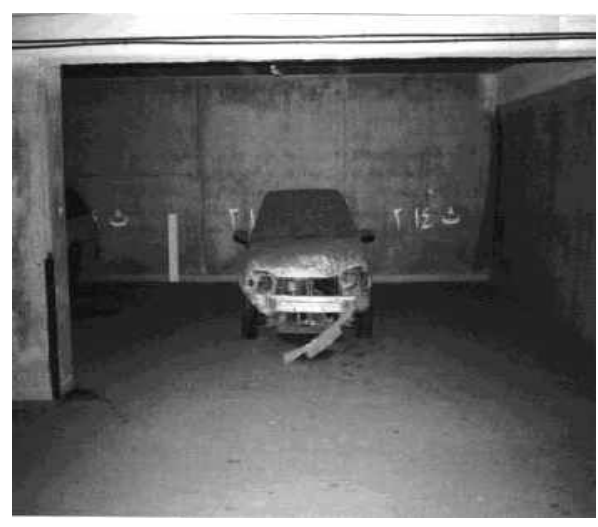

Fig. 38. A parking space occupied by a broken car 


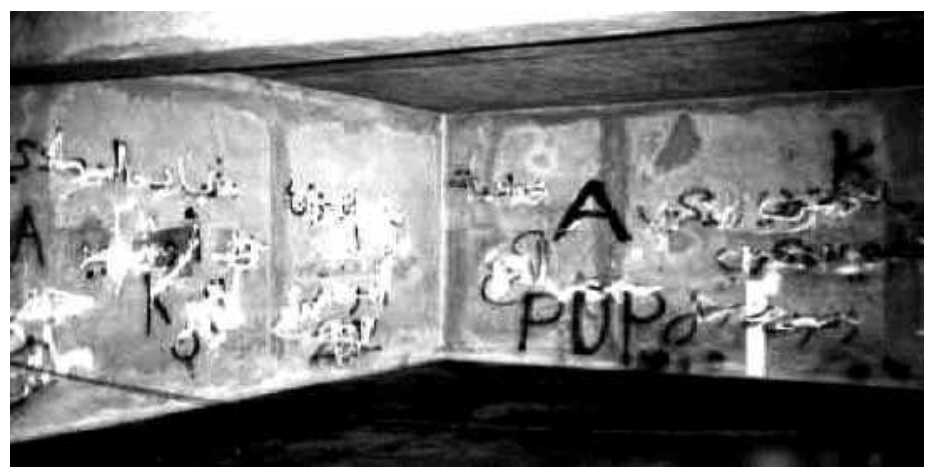

Fig. 39. Graffiti in one of the garages

4.2.7.2.5. Children's playgrounds: Those who were dissatisfied with the playgrounds thought that they were a waste of land or not a life necessity. Other believed that they would feel that their children would be unsafe in these spaces.

\subsubsection{Social Issues}

4.2.7.3.1. Relationship with neighbors: Many residents pointed out the poor or absent social relationship with neighbors in the same or other buildings. However, such a relationship might be limited to those next door or of the same ethnic background. Some respondents claimed that the Supervision Committee did not have any social role in creating a sense of community among residents.

Furthermore, a resident mentioned that the presence of many people in a small area made social communication difficult. That was in addition to the diversity of income and/or education of residents that has created some serious differences.

4.2.7.3.2. Social and moral problems: The presence of crime and moral problems made many residents feel unsafe in the premises. Thefts and drug use or dealing were among the troubles that have threatened the security of the complex. Other residents mentioned the existence of sexual harassment in public areas such as sidewalks or lobbies. Indeed, one resident claimed that there were a few apartments that have been used for immoral or illegal activities (e. g., adultery or alcohol manufacturing). Another said that there were a few incidents of child molesting. That was in addition to suicide cases and spread of smoking among children and teens that gathered late night in common areas annoying neighbors with their fights and noise. One respondent said that storages and garages, being secluded and dark, have become popular places for raping little children and meetings between young girls and boys.

Many residents expressed their concern about flirting from neighboring windows and balconies. Slang or bad words and graffiti covered several walls and elevators, indicating the deepness of the social/moral atmosphere of Jeddah Rush Housing (Fig. 40).

\subsubsection{Maintenance Issues}

4.2.7.4.1. Unit and complex maintenance and cleanness: The most issue that repeatedly commented on by residents and those who have been interviewed 
was the maintenance of their unit, which suffered from deteriorated plumbing systems or damaged ceilings or walls due to water leaking from upper units (Fig. 41). Many residents frustratingly referred this deterioration and poor maintenance to the carelessness of the Supervision Committee and some residents, especially renters.

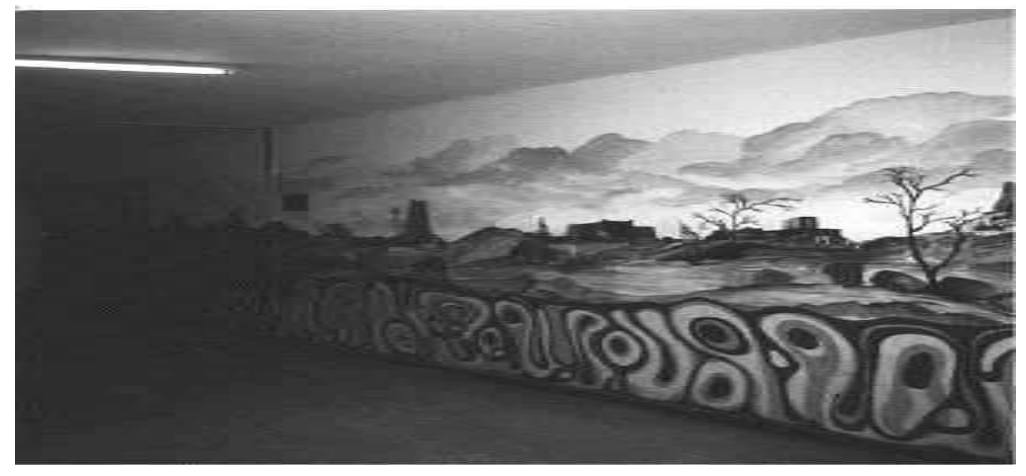

Fig. 40. Personalizing a shared corridor without the permission of neighbors



Fig. 41. Deteriorated plumbing pipes and damaged ceilings due to water leak from upper units

In fact, some residents said that the leak of water from the pipes of their or upper units has turned their apartment into a swamp with awful smells. Such a problem would impact the physical safety of the building. On the other hand, the Supervision Committee insisted that the maintenance of the inside the unit was the responsibility of the tenants, and its obligation was confined to the outside of the unit [19]. The committee in its newsletter repeatedly mentioned the careless attitude of some residents toward the maintenance of their apartments [15]. It claimed that its financial resources were limited and could barely handle the external maintenance (Fig. 42). 



Fig. 42. Maintenance instruction manual and a newsletter regularly published by the Supervision Committee

Source: [20 and 21]

In a rare move and as the leak of water between units became severe, the Committee decided to repair the plumbing pipes of most affected apartments on its own expense. Nonetheless, such an attempt did not succeed. Residents were not corporative to allow maintenance labors to enter their units. Some were not in their apartments most of the time while others complained about the inconvenience of the time of the maintenance or gave excuses such as a presence of a guest, etc. As a result, the maintenance groups made several changes in their schedule, but that did not work either. This had worsened the plumbing situation in the project [15].

As far as the maintenance of the buildings or complex (outside the apartments), the real challenge the Supervision Committee faced with was the refusal of some residents to pay the annual maintenance fees. Some residents thought that public areas such as sidewalks and gardens as well as utilities (water, electricity, etc.) were damaged so they stopped paying the fees. They expressed their concern about the broken elevators, septic tanks that flooded weekly, and irregular availability of water and electricity. A few years ago, the amount collected for the complex maintenance was USD 187,000 instead of 535,000. This has affected the Committee's maintenance efforts [15].

Besides this, the smoke coming from the restaurants of the ground floor has badly changed the color of the exterior of the towers. Other residents said that there was not any supervision of the maintenance work by the Committee or representatives. Yet, when the Committee intervened, unqualified workers did the maintenance job.

Cleanness was another issue that many residents disappointedly mentioned. This matter was reflected in the garbage that was found between the towers and in garages, lobbies and corridors (Fig. 43). In addition to ruthless graffiti, bad smells often came out from emergency exists and staircases where residents threw their daily trash. Respondents claimed that there was no concern for cleaning in the project by the Committee or/and other residents.

The Supervision Committee, however, said that cleaning around the buildings was the responsibility of the Municipality, which sometime ignored the project [21]. Also, each tower had a modern system of trash collection, but due to some vandalism, 
misuse and bad smell coming out from garbage, the Committee stopped allowing residents to utilize the system.

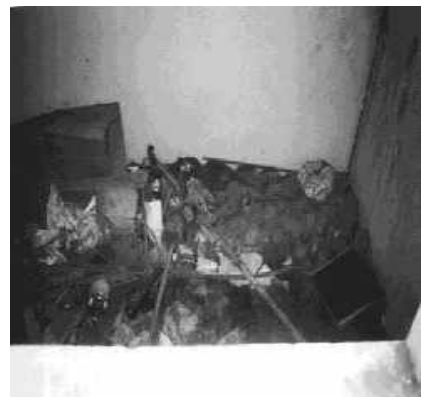

Utility room

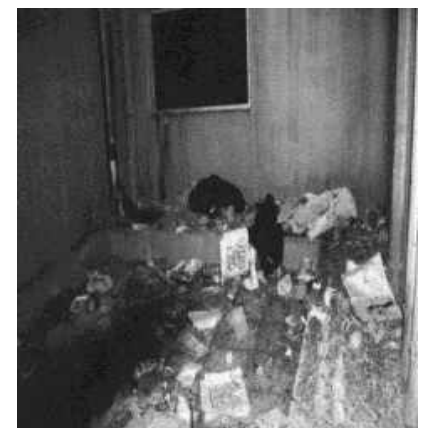

Airshaft

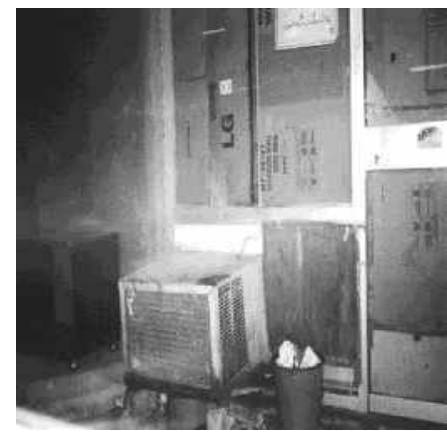

Lobby

Fig. 43. Unclean public spaces

4.2.7.4.2. Reasons for damages: Many residents pointed out the absence of the Committee in managing and assuring the welfare of the complex. Also, the Committee had no rules of punishing those residents who caused damages in their building. Several residents mentioned that the Committee should set orientation lectures and teach ignorant residents how to take good care of the complex. Some respondents felt that irresponsible behavior was another reason for damages. For instance, various residents threw their garbage anywhere or left lights of corridors on for years until they got burned. Children played football in corridors causing damages to walls, doors, lights, etc. Teens gathered in groups fighting. A resident showed a surveyor blood marks of fights on walls. Also, some residents did not know how to for example operate an elevator, causing repeated damage to it.

A resident remarked that there have been many times when the maintenance laborers left the maintenance work incomplete due to not being paid by the Committee. And often those labors were not qualified. Another respondent stated that the long time gab (more than 10 years) between the compellation of the project and its occupancy had some physical impacts on the project.

\subsubsection{Security and safety in the building and complex}

Most residents commented on the issue of parking security (Fig. 44). They felt that the garages have been used for committing various kinds of crime due to lack of security. These garages were dark, dirty, less maintained and often used for drug use and other immoral activities. Indeed, a terrorist activity has taken a place in one of the garages where the police discovered large quantities of ammunitions and bombs stored in them. Also, several cars full of drugs and alcohol were reported there. This is in addition to the many cars that have been stolen from these garages. 


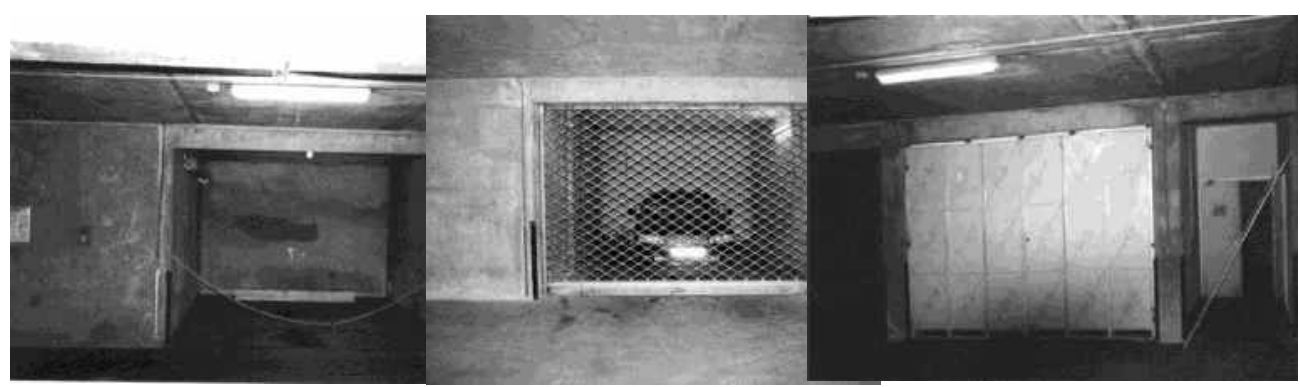

Fig. 44. Placing a chain or installing a door by residents for security of the car parking spaces

A few years ago, a huge fire broke out in one of the units. Fire trucks were unable to enter the complex due to double or improper parking in the barriers of the garages. This brings us to the issue of traffic around the project. Due to the heavy traffic congestion generated by the complex and surrounding areas, a network of bridges and tunnels has been initiated around the site in 2005. Yet, the network is not finished yet because of traffic and other complications in the area, which is considered a major traffic node in Jeddah [12].

Lack of security has increased the residents' fear of a fire or serious incident that would be hard to overcome. Some residents were also concerned about the safety of their children indoor and outdoor. Children's playgrounds, being unattended, were unsafe (Fig. 45). Although the Committee in its newsletter listed certain measures residents should implement to address the safety of their children, there has been an accident of a death of a child reported in the complex in 2005. In this horrific accident, the child of four year old failed down from the 17th floor of his tower. He died immediately. He sneaked through the metal bars his parents placed on one of the balconies of the unit [17 and 22].
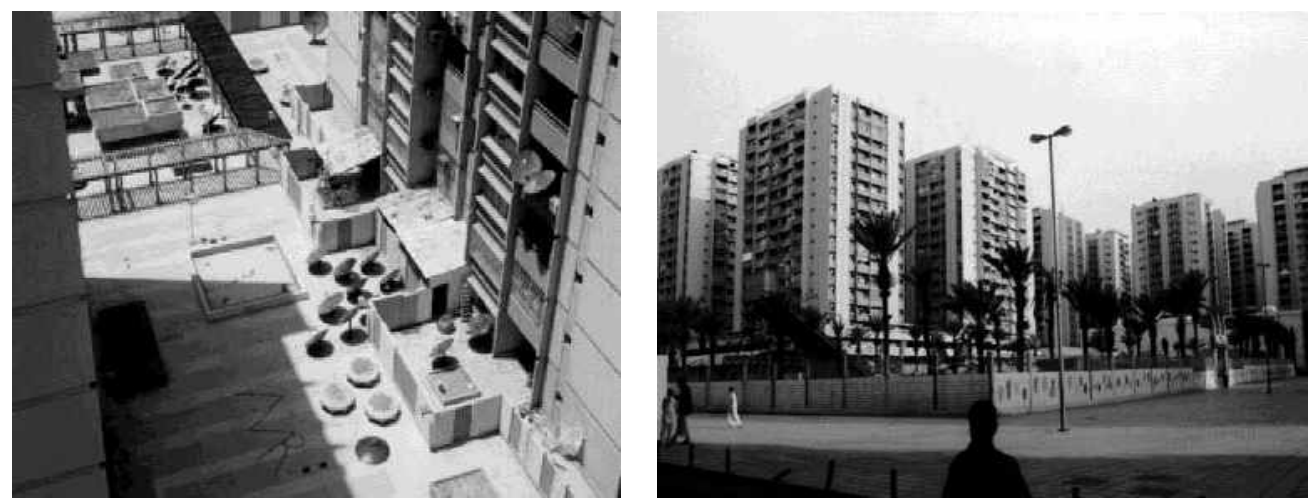

Fig. 45. Deserted plazas and playgrounds

Theft was among the most crimes witnessed by residents. A respondent claimed that one of the neighboring units was broken into by thieves in broad daylight. Another said that he witnessed the killing of an African man who was thrown out from 
the 16th floor. Also, some apartments were converted by tenants or gangs into alcohol factories or suspicious activities.

Some minor incidents were mentioned by residents, indicating lack of security, safety and moral values in the complex. For instance, disturbance by loud music from or family arguments in a neighboring unit was very common.

\subsubsection{Conclusive comments}

Toward the end of the questionnaire, many respondents and those who were interviewed revealed their final points of view on Jeddah Rush Housing. The most comment made was that this complex was a failing project and needed to be demolished. Other demanded replacing the project with another one that was more secured, safe, well maintained, clean and with better residents' awareness. Some said that the physical and social deterioration of the project has turned the complex into another slum in Jeddah. A few residents demanded an immediate intervention from a higher authority for a reliable Supervision Committee and more services (i. e. clubs) for children and teens. A resident asked for the prevention of renting the units. He said that these units were not meant for investment.

\subsection{Recommendations by Residents}

Several residents who have been interviewed came up with the following suggestions in order to stop or at least reduce the social and physical problems in Jeddah Rush Housing Project:

- Enhancing the sense of belonging and responsibility of residents by workshops, seminars and lectures organized and supervised by some residents, invited speakers, and the Supervision Committee.

- Setting up harsh fines by the Supervision Committee against any resident that creates damage or annoy other residents.

- Establishing a regular maintenance program by both the residents (or their representatives) and the Committee.

- Redesigning the common areas such as sidewalks and playgrounds by making them socially attractive and secured.

- Hiring a company that is specialized in security.

- Increasing communication between residents and the Supervision Committee.

- Publishing more materials by the Committee to expand residents' awareness.

- Removing all satellite dishes from the facades and placing them on the roof.

- Redesigning the front facades in order to create a harmony between the exterior of the apartments and that of the shops in the ground floor.

- Expanding the use of the garden to strengthen social relationship between residents.

- Maintenance outside the unit should be contracted out to a professional company, The USD 367 paid by each unit is sufficient enough to cover the cost.

- Enhancing the security of the garages, which should be heavily guarded to prevent vandalism, crimes and strangers' cars from entering.

- Seeking more funds from the government to support the maintenance and supervision work by the Committee. 
The author thinks that the above recommendations by residents are genuine. Nevertheless, their implementation will not be easy and would take time. Also, more detailed studies based on the current social and physical problems of the complex are still needed. Livability studies focusing on the issues of safety, security, privacy, and sense of community are required.

\section{SUMMARY AND CONCLUSIONS}

After its completion, the Rush Housing Project of Jeddah that features high-rise towers remained unoccupied for more than a decade. However, the project started to show scenarios of social and physical decays after being occupied by residents. The author consequently surveyed the complex in an attempt to find out the nature and scope of these issues.

The investigation has realized the presence of various social and other problems that varied from social disintegration, crime, and safety to poor maintenance and services. These problems were a major concern to residents who participated in the survey (questionnaires and interviews) of this research.

There is no doubt that the Rush Housing Project of Jeddah adds another example of unsuccessful public housing to similar projects of high-rise residential buildings worldwide. These projects have failed to create a decent living to occupants, and themselves turned out to be problematic to the surrounding social and urban context.

\section{REFERENCES}

1. Amerigo, M. A. Psychological Approach to the Study of Residential Satisfaction, Residential Environments. London, (2002).

2. Berkiz, Lale and Omer Lutfi Kellekci. "Mass Housing Residents Satisfaction with their Housing and Environment", Open House International. Vol. 32, No. 1, (2007), pp. 41-49.

3. Michelson, W. Environmental Choice, Human Behavior, and Residential Satisfaction. Oxford University Press, New York, (1977).

4. Francescato, G., S. Weidemann, and J. Anderson. Residential Satisfaction: Its Uses and Limitations in Housing Research, Housing and Neighborhoods. Greenwood press, New York, (1987).

5. Rainwater, Lee. Behind Ghetto Walls: Black Families in a Federal Slum. Aldine Pub. Co., Chicago, (1970).

6. Newman, Oscar. Creating Defensible Space. Center for Urban Policy Research, Rutgers University, (1996).

7. Popkin, Susan J. and Mary K. Cunningham. "CHA Relocation Counseling Assessment", Final Report. The Urban Institute, Metropolitan Housing and Communities Policy Center, Washington, DC, (2002).

8. Al-Shareef, Mohamed, Majdi Hariri, Thamer Al-Harbi, and Abdul Hamed Al-Bes. Al-iskan fie Almamlaka Alarabia Asaudia: Tomohat wa Enjazat (Housing in 
Saudi Arabia: Ambitions and Achievements). Ministry of Housing and Public Works, Riyadh, (1999).

9. "The Remarkable Transformation of Dammam-Dhahran-Alkhobar Triangle", www.saudiembassy.net, (visited 15 May, 2007).

10.Bahamam, Ali Salem. Al-iskan fie Almamlaka Alarabia Asaudia: Oshroun A'mn min Al-Enjazat (Housing in Saudi Arabia: 20 Years of Achievements). King Saud University, Riyadh, (2002).

11."Housing for All: Duties and Responsibilities in Saudi Arabia", a paper submitted by the Saudi Delegation to UN Habitat Conference, (1987).

12.Bin Marzoq, Aied. "Haie al- Sharafiyah Shahed Alla Alwafa (Al- Sharafiyah District is a Witness of Loyalty). Asharqalawsat. No. 10237, 8 December, (2006), p. 19.

13."Ministry of Housing and Public Works, Deputy Ministry for Housing Affairs", Report. Ministry of Housing and Public Works, Riyadh, (1994).

14."Wazeer Al-Takhtet: $62 \%$ men al-Osar al-Saudia Tamlek Manzel (62\% of Saudi Families Own Houses", Al-Iqtisadiah. No. 54087, 18 September, (2007), p. 3.

15.Supervision Committee. Report No. 1 on Jeddah Rush Housing Project. 28 September, (2000).

16.Ministry of Housing and Public Works. "Mashro' Iskan Al-Sharafiyah (AlSharafiyah Housing Project)", Leaflet. Ministry of Housing and Public Works, Riyadh, (2003).

17.Supervision Committee. Report No. 2 on Jeddah Rush Housing Project. 27 November, (2000).

18. Al-Joua'ed, Abdulah. "Bemonasabet al-Yaom al-Alame lel Adefa' al-Madamie (On the Occasion of the World Day of Civil Defense", Al-Jazerah. No. 12563, 12 March, (2003), p. 1.

19."Almashakel Tohaser A'maer Aliskan wa Tohadedha bel alikhla' (Problems Surround the Housing Towers and Threaten them by Evacuation)", Okaz, No. 13637, 24 August, (2000), p. 1.

20.Ministry of Housing and Public Works. Dalel al-Erashadat (Instructions Manual). Ministry of Housing and Public Works, Riyadh, (2000).

21.Supervision Committee. Report No. 3 on Jeddah Rush Housing Project. 26 March, (2001).

22."Tefl fie alrabe'ah lakyah hatfoh ethr sokoteh men Iskan al- Sharafiyah (A Four Year Old Child Died as He Failed from the $17^{\text {th }}$ Floor of one of Jeddah Rush Housing Project)", Okaz. 18 February, (2005), p. 15.

\section{تقييم السكن في مشروع الإسكان العاجل بجدة}



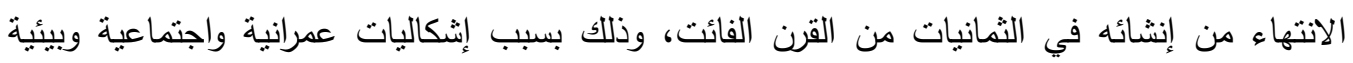
محتمل أن تؤدي إليها أبراج المشروع العالية بعد توزيعها على المواطنين، لكن وفي وسط التسعينات، تم 
توزيع الوحدات السكنية من المشروع على الأسر السعودية المستحقة، وكما كان متوقع، أصبح المشروع مصدر للانحدار العمراني والاجتماعي في المدينة. تقوم هذه الدراسة بالتحقق من المشاكل الاجتماعية التي صاحبت الإقامة في مشروع الإسكان العانية العاجل في

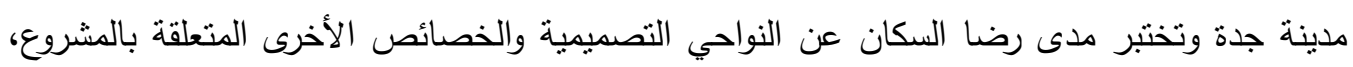


المشروع. كلمات مفتاحية: إسكان عام، جدة، مناطق عشوائية، تفكلك اجنماعي، أبراج سكنية. 